\title{
SELF-EXPANDING METAL STENT FOR THE MANAGEMENT OF BLEEDING ESOPHAGEAL VARICES - SINGLE CENTER EXPERIENCE
}

\author{
Gh.P.Ghidirim, I.V.Mishin, A.N.Dolghii, Gh.Ch.Bunic, Gh.M.Zastavnitsky
}

Department of Surgery N. 1 and Laboratory of Hepato-Pancreato-Biliary Surgery, State University of Medicine and Pharmacy "N. Testemitanu”, National Centre of Emergency Medicine, Chisinau, Moldova

\section{ЗАСТОСУВАННЯ САМОРОЗПРАВНИХ МЕТАЛЕВИХ СТЕНТІВ У ЛІКУВАННІ КРОВОТЕЧ З ВАРИКОЗНО РОЗШИРЕНИХ ВЕН СТРАВОХОДУ - ОДНОЦЕНТРОВИЙ ДОСВІД}

Резюме. До теперішнього часу ендоскопічне лігування (ЕЛ) є стандартним методом лікування кровотеч з варикозно розширених вен стравоходу (ВРВС) 3 кращими результатами в порівнянні з склеротерапією. Частота безуспішності ендоскопічного гемостазу становить близько $10 \%$ та асоціюється 3 високою летальністю. Вибір методу гемостазу в даній ситуації і при масивних кровотечах залишається суперечливим. Новим методом вирішення даної проблеми може вважатися використання саморозправних металевих стентів. У даному дослідженні автори описують досвід використання таких стентів $(\mathrm{n}=14)$ при масивних кровотечах з ВРВС $(\mathrm{n}=9)$ і кровотечах після ЕЛ $(\mathrm{n}=5)$.

Ключові слова: варикозне розширення вен стравоходу, кровотеча, стент.

Esophageal variceal (EV) bleeding is a severe and life threatening complication of portal hypertension $(\mathrm{PH})$, while endoscopic failure to control hemorrhage is even a more dramatic situation. Over the last decades, various treatment options have been used for the management of bleeding EV, including pharmacologic vasoconstriction ( $\beta$-receptor blockade and/or nitrates), mechanical EV compression with a Minnesota or Sengstaken-Blakemore tube and various endoscopic as well as interventional radiology techniques $[1,2]$. Up to date endoscopic band ligation (EBL) for bleeding $\mathrm{EV}$ is considered the standard of care for this group of patients since EBL is superior to sclerotherapy [3]. The rate of EBL and sclerotherapy failure to achieve hemostasis in bleeding EV is $10 \%$ of cases [4]. Another potentially fatal complication following successful EBL is the early band slippage and bleeding esophageal ulcers [5].

Although these advanced management procedures resulted in improved survival rates of patients after bleeding EV, mortality is still high, particularly in patients with advanced liver disease, even after initially successful hemostasis [6]. The poor treatment results for bleeding EV in patients with advanced liver disease (Child-Pugh class C) are due to a reduced liver capacity to produce coagulation factors [7].

Recently, a novel management procedure, the self-expanding metal stents (SEMS) have become available as a treatment option for bleeding EV as well as for the management of the specific complications of EBL (esophageal ulcer) or endoscopic failure [8]. The use of SEMS is not influenced by endoscopic visualization and the preliminary results have been encouraging since the reported success rates (successful hemostasis) are between 70-100\% [9]. Unlike other treatment modalities, SEMS not only allow to achieve hemostasis, which is the goal of any treatment modality, it also can be a temporary or definitive procedure [7].

Purpose of the study: Since the cumulative experience using SEMS in endoscopic hemostasis failure for bleeding EV, further studies are necessary regarding the method's efficacy as a potential salvage procedure. Under these circumstances our aim was to assess SEMS hemostatic efficacy in severe variceal haemorrhage in patients with bleeding EV and endoscopic treatment failure.

Material and methods. During the last two years a total number of 14 adult patients with refractory to standard therapy (EBL) bleeding $E V$ were treated in the first Department of Surgery and Laboratory of Hepato-Pancreato-Biliary Surgery, National Centre of Emergency Medicine. There were 8 male and 6 female with the mean $\pm S D$ age $51.1 \pm 2.63$ (range 32-69) years. The etiology of bleeding EV was viral (HBV, $H C V)$ liver cirrhosis induced portal hypertension in all cases. The main selection criterion was endoscopic treatment failure. A removable covered SEMS (SX-ELLA stent Danis, $135 \times 25 \mathrm{~mm}$, ELLA-CS, Hradec-Kralove, Czech Republic) was used in all cases. The mean SEMS used per patient was $1.25 \pm 0.18$ (range 1-3). The mean $\pm S D$ SEMS installation time was $4.79 \pm 0.51$ (range 3-10) min. Bleeding EV and portal hypertension were diagnosed by initial upper GI endoscopy and ultrasonography (a dilation of the portal vein $\geq 15 \mathrm{~mm}$ or ascites). All definitions were used according to Baveno Consensus (I-V) conferences and liver function was assessed according to Child-Pugh 
and the MELD (Model for End-stage Liver Disease) [10].

Stenting procedure: After EBL failure or postbanding bleeding esophageal ulcers, all patients were managed with a fully covered SEMS using the SX-Ella stent Danis; Ella-CS, Hradec Kralove, Czech Republic with a length of $135 \mathrm{~mm}$ and a diameter of $25 \mathrm{~mm}$. An endoscopically placed guidewire was used to achieve correct SEMS insertion. The standard delivery system provided with an inflatable balloon was used for positioning the distal stent edge at the esophagogastric junction (Fig. 1). The delivery system was removed after stent positioning and balloon deflation. The proper stent position as well as hemostasis was confirmed by upper GI endoscopy (Fig. 2).

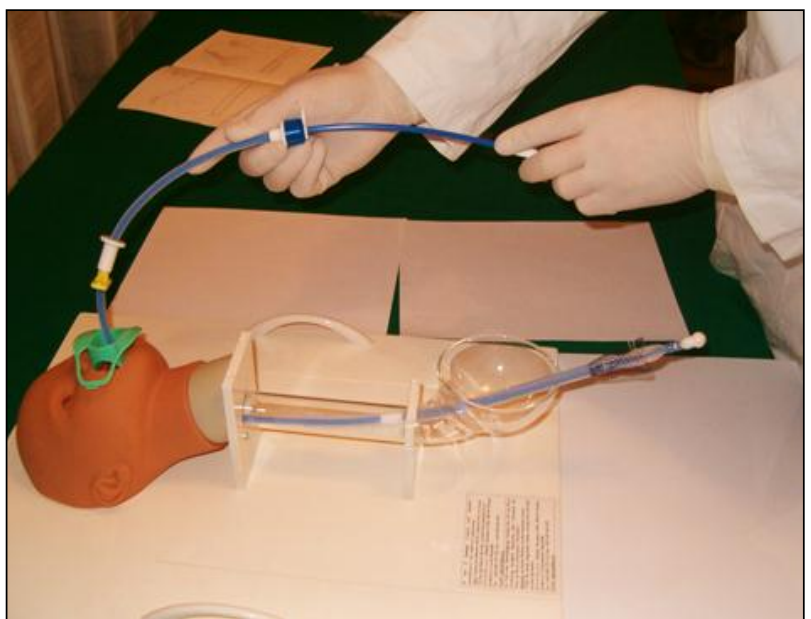

Fig. 1. The standard provided delivery system.

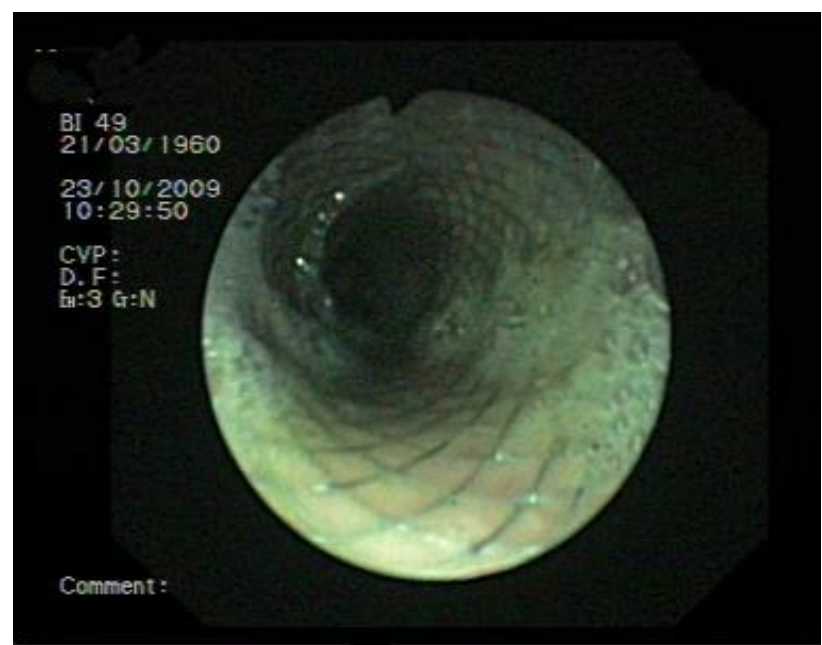

Fig. 2. Upper GI endoscopy - effective hemostasis and correct SEMS position.

Results. Emergency upper GI endoscopy revealed massive bleeding EV $(n=9)$ or postbanding esophageal ulcers $(n=5)$. The mean \pm SD Child-Pugh and MELD scores were 9.54 \pm 0.44 (range 7-12) and $17.68 \pm 1.7$ (range 9.2-27.8) respectively. Initial SEMS hemostatic efficacy was $100 \%$. Standard procedure SEMS delivery was feasible without difficulties using the provided system and led to immediate hemostasis in all cases as confirmed by upper GI subsequent endoscopy. The mean $\pm \mathrm{SD}$ stent in situ time was $94.31 \pm 14.09$ (range 18-170) hours. Partial distal stent migration was documented on X-ray and CT-scan in 5/12 (41.6\%) and stent reposition was achieved by second-look endoscopy (Fig. 3, 4).

The SEMS were removed using the standard removal device for nontraumatic extraction. During stent extraction the removal device the SEMS and

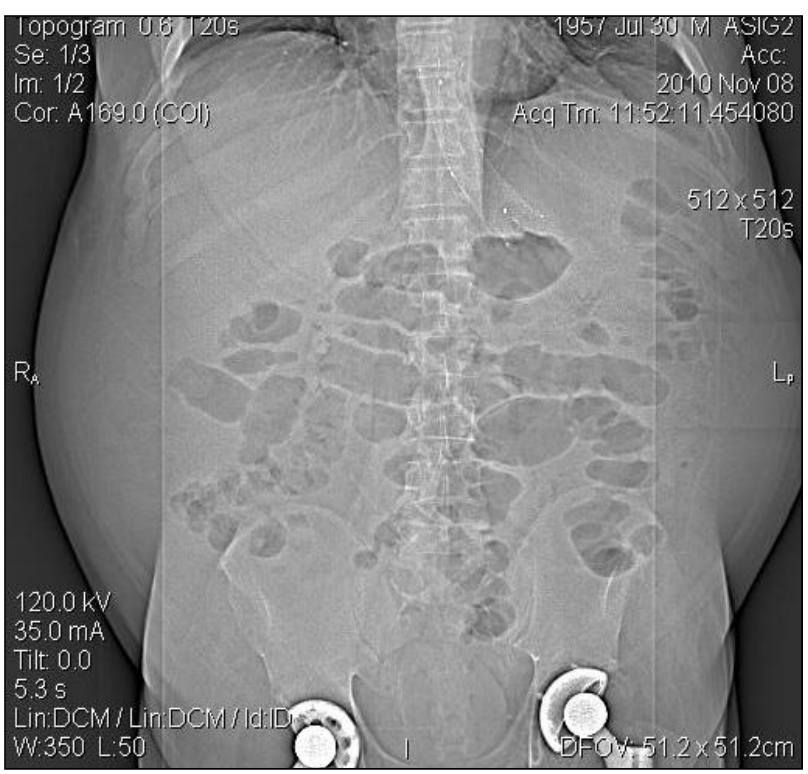

Fig. 3. CT-scan SAME in situ.

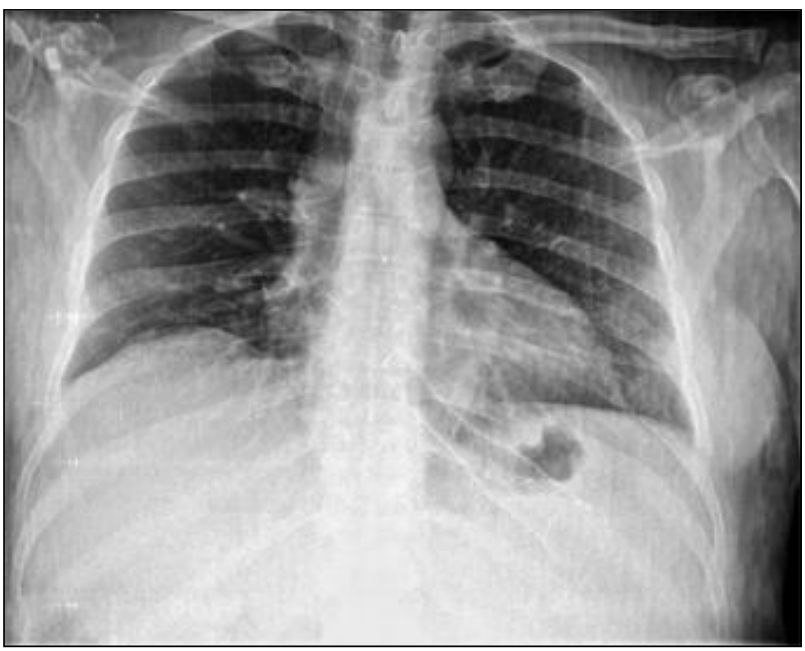

Fig. 4. Chest $x$-ray-partial SAME migration.

the wire were recovered simultaneously. Upper GI endoscopy was performed straight after SEMS removal in order to assess rebleeding, as well as necessity of further endoscopic treatment for EV. The definitive hemostasis was achieved by EBL with a MBL-10F Wilson Coock ${ }^{\circledR}$ device in 7 cases and by EV ligation with using the detachable nylon ring (MAJ-339; Olympus) in 2 cases. In 5 cases stenting was the only procedure used for hemostasis.

Unlike other published studies we experienced no major SEMS induced complications (bronchial 
compression or impairment of the pulmonary function). The overall 30-days mortality was $35.7 \%$ $(5 / 14)$. Tanatogenesis was induced by hepatic failure $(n=3)$, bleeding EV distally to the SEMS distal end $(n=1)$ and hemorrhagic stroke $(n=1)$.

Discussion. Bleeding EV is a frequent and often fatal complication of portal hypertension and liver cirrhosis. Current recommendations for the treatment of acute bleeding EV are to combine hemodynamic stabilization, antibiotic prophylaxis, pharmacologic agents, and endoscopic treatment. Immediate EBL of bleeding EV is the treatment of choice [4]. However, despite the usage of the current goldstandard pharmacologic and/or endoscopic treatment procedures, refractory bleeding EV or early recurrence within 5 days occurs in $15 \%$ to $20 \%$ of patients [9].

In case of treatment failure of the bleeding EV and if hemorrhage is hemodynamically insignificant, a second endoscopic therapy can be attempted. If this fails, or if bleeding is severe, balloon tamponade (BT) is usually effective to achieve temporary hemostasis until a definitive treatment method is applied. Another available is the insertion of a transjugular intrahepatic portosystemic shunt (TIPS) [8].

These techniques (BT and TIPS) are effective to achieve hemostasis in patients with bleeding EV, but they have important limitations: 1) BT is a temporary measure and can be considered only as a bridge to definitive therapy; 2) TIPS insertion is technically challenging and is not available in all centers, thus, a potential transfer of a critically ill patient is required; 3) TIPS carries the risk of liver function worsening and encephalopathy and in most series is associated with a survival rate of only $50 \%$ at 1 year. Our study as well as others demonstrate that SEMS represent an attractive treatment modality for endoscopic refractory bleeding EV. Indeed, the SEMS hemostatic efficacy was $100 \%$. Thus SEMS is a sufficient method to stop bleeding immediately and stabilize the patient either as a definitive or for further therapeutic interventions (TIPS or liver transplantation). For the patients (10-15\%) who fail pharmacologic or/and endoscopic therapy [4], a placement of SEMS offers a successful alternative hemostatic treatment option with a high rate (up to $100 \%$ ) of immediate EV bleeding control [9]. Similar results regarding SEMS hemostatic efficacy $(100 \%)$ was achieved in the present study.

As with the balloon tamponade, hemostasis is obtained because of SEMS compression of the bleeding esophageal varices. However, the SEMS provide some significant advantages compared with balloon tamponade: (i) standardized and optimized expansion power and pressure to the esophageal wall, thus the potential risk of injury is minimal; (ii) stent insertion is a standard procedure; (iii) the stent cannot be removed or dislocated by the agitated patient; and (iv) the stent lumen guarantees physiologic saliva drainage and even makes oral fluid and food intake possible.

The potential stent disadvantages are: (i) standard stents are usually placed under radiographic guidance; (ii) non-optimal configuration of the stent may cause distal migration; (iii) risk of necrosis and fistula formation; (iv) acute bronchial obstruction; and (v) stent removal-related complications [9], all the above mentioned disadvantages are reduced to minimum with the Danis SEMS.

Since the SEMS has to be removed after approximately 1 week (range 6-14 days) and $94.31 \pm 14.09$ (range 18-170) hours in the present study, the method has only a temporary hemostatic effect on EV bleeding, thus additional modalities to reduce portal hypertension are warranted. However, the patient's individual liver function assessment according to Child-Pugh and the MELD profile should be critically reviewed. The SEMS are useful in order to control EV bleeding and may facilitate the initial patient's stabilization after standard endoscopic therapy failure and might enable alternative treatment options [7]. Stenting for refractory EV bleeding can be easily performed in virtually any clinical setting without the use of fluoroscopy [9].

Previously published studies have demonstrated the SEMS hemostatic efficacy when the bleeding source was located in the esophagus, since the hemostatic effect does not affect gastric varices, located distally to the gastroesophageal junction. According to the previously published study by Zehetner et al. [10] the stent migration into the stomach occurred frequently $(>20 \%)$, the SEMS migration rate in our series was $5 / 12(41.6 \%)$. Under these circumstances an encoring system had to be improvised in order to prevent SEMS migration (Fig. 5)

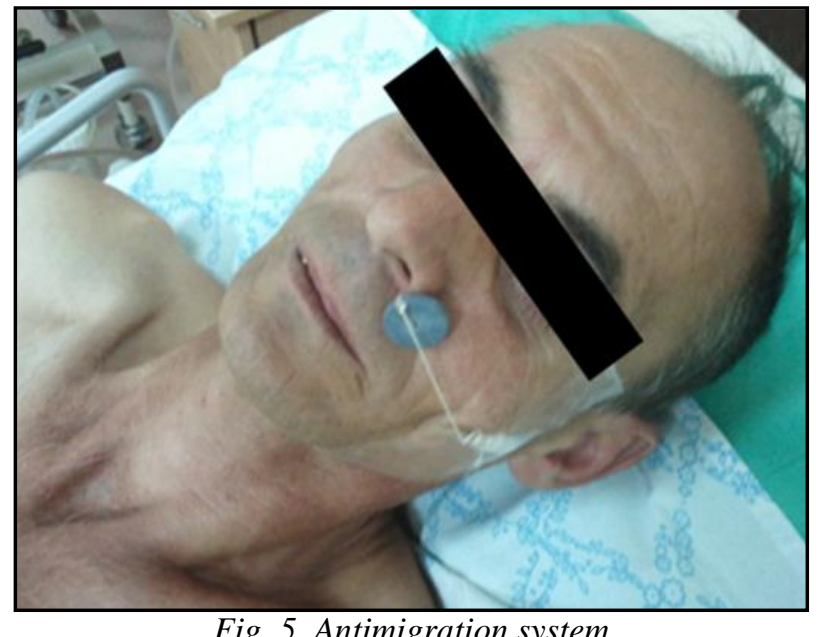

Fig. 5. Antimigration system.

Unlike in the other studies no stent-related compression of the airways with an acute deterioration of the respiratory function following compression of the left main bronchus was observed in the preset study. A major limitation of our study is the relatively low number of patients included.

Conclusions. The preliminary results demon- 
strate that stenting is an effective life-saving hemostatic procedure in high-risk patients with severe esophageal variceal bleeding and endoscopic hemo- stasis failure as well as postbanding esophageal ulcers. Final conclusions will be reached after gaining experience with this new method on larger series.

\section{References}

1. Cerebral embolism following $N$-butyl-2-cyanoacrylate injection for esophageal postbanding ulcer bleed: a case report / S.Sachithanandan, S.Tan, Y.M.Chan [et al.] // Hepatol. Int. - 2009. - Vol. 3, № 3. - P. 504508. 2. Ferguson J.W. Review article: the management of acute variceal bleeding / J.W.Ferguson, D.Tripathi, P.C.Hayes // Aliment. Pharmacol. Ther. - 2003. - Vol. 18, № 3. - P. 253-262. 3. Garcia-Tsao G. Management of varices and variceal hemorrhage in cirrhosis / G.Garcia-Tsao, J.Bosch // N. Engl. J. Med. 2010. - Vol. 362, № 9. - P. 823-832. 4. D'Amico G. Cooperative Study Group. Upper digestive bleeding in cirrhosis. Post-therapeutic outcome and prognostic indicators / G. D'Amico, R. De Franchis // Hepatol. 2003. - Vol. 38, № 3. - P. 599-612. 5. Mishin I. Early spontaneous slippage of rubber bands with fatal bleeding: a rare complication of endoscopic variceal ligation / I.Mishin, A.Dolghii // Endoscopy. - 2005. Vol. 37, № 3. - P. 275-276. 6. Predictors of early re-bleeding and mortality after acute variceal haemorrhage in patients with cirrhosis / K.Bambha, W.R.Kim, R. [et al.] // Gut. - 2008. - Vol. 57, № 6. - P. 814820. 7. Acute management of refractory variceal bleeding in liver cirrhosis by self-expanding metal stents / A.Dechêne, A.H.El Fouly, L.P. [et al.] // Digestion. - 2012. - Vol. 85, № 3. - P. 185-191. 8. Mishin I. Implantation of self-expanding metal stent in the treatment of severe bleeding from esophageal ulcer after endoscopic band ligation / I.Mishin, G.Ghidirim, A.Dolghii [et al.] // Dis. Esophagus. - 2010. - Vol. 23, № 7. P. 35-38. 9. A self-expanding metal stent for complicated variceal hemorrhage: experience at a single center / G.Wright, H.Lewis, B.Hogan [et al.] // Gastrointest. Endosc. - 2010. - Vol. 71, № 1. - P. 71-78. 10. de Franchis R. Evolving consensus in portal hypertension. Report of the Baveno IV consensus workshop on methodology of diagnosis and therapy in portal hypertension / R. de Franchis // J. Hepatol. - 2005. - Vol. 43, № 1. - P. 167-176.

\section{ПРИМЕНЕНИЕ САМОРАСПРАВЛЯЮЩИХ- СЯ МЕТАЛЛИЧЕСКИХ СТЕНТОВ В ЛЕ- ЧЕНИИ КРОВОТЕЧЕНИЙ ИЗ ВАРИКОЗНО РАСШИРЕННЫХ ВЕН ПИЩЕВОДА - ОД- НОЦЕНТРОВОЙ ОПЫТ}

Резюме. До настоящего времени эндоскопическое лигирование (ЭЛ) является стандартным методом лечения кровотечений из варикозно расширенных вен пищевода (ВРВП) с лучшими результатами по сравнению со склеротерапией. Частота безуспешности эндоскопического гемостаза составляет около $10 \%$ и ассоциируется с высокой летальностью. Выбор метода гемостаза в данной ситуации и при массивных кровотечениях остается противоречивым. Новым методом решения данной проблемы может считаться использование металлических саморасправляющихся стентов. Авторы описывают опыт использования металлических саморасправляющихся стентов $(\mathrm{n}=14)$ при массивных кровотечениях из ВРВП $(\mathrm{n}=9)$ и кровотечениях после ЭЛ $(\mathrm{n}=5)$.

Ключевые слова: варикозное расширение вен пищевода, кровотечение, стент.

\section{SELF-EXPANDING METAL STENT FOR THE MANAGEMENT OF BLEEDING ESOPHA- GEAL VARICES - SINGLE CENTER EXPE- RIENCE}

Abstract. Up to date endoscopic band ligation (EBL) for bleeding esophageal varices (EV) is considered the standard of care for this group of patients since EBL is superior to sclerotherapy. The frequency of endoscopic hemostasis failure is $10 \%$ of bleeding events and is associated with high mortality. The treatment modality for endoscopic hemostasis failure in patients with portal hypertension and massive bleeding EV is controversial. Recently, a novel successful treatment modality for EV bleeding using self-expanding metal stents was published. This study was aimed to evaluate our experience $(n=14)$ with the implantation of self-expanding metal stents for the management of severe EV bleeding $(n=9)$ and bleeding after $\operatorname{EBL}(\mathrm{n}=5)$.

Key words: esophageal varices, bleeding, stent.

State University of Medicine and Pharmacy "N. Testemitanu", National Centre of Emergency Medicine, Chisinau, Moldova 